Economics Development Analysis Journal 9 (2)(2020)

\title{
Tourism Industry Competitiveness of Semarang Municipality
}

\author{
Hertiana Ikasari ${ }^{1 凶},{ }^{2}$ Ida Farida
}

Management Study Program, Faculty of Economics and Business, Dian Nuswantoro University

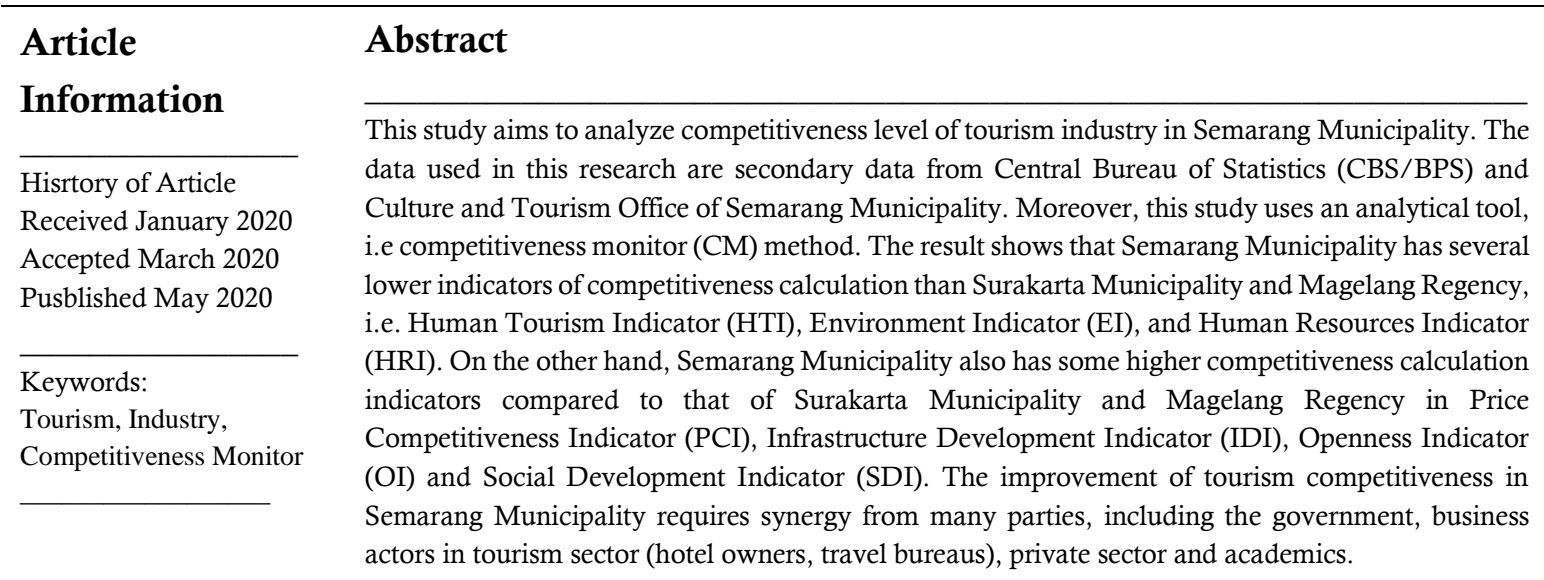

\footnotetext{
${ }^{\circledR}$ Corresponding author :

Jalan Nakula I No. 5-11 Semarang, Jawa Tengah Indonesia

Email: hertiana.ikasari@dsn.dinus.ac.id
} 


\section{INTRODUCTION}

Tourism is one of the leading sectors in a municipality or country. The increasing number of tourist destinations and investments make tourism become a key factor in export earnings, job vacancy creation, business development and infrastructure. Tourism has continuously expanded and diversed and has become one of the largest and fastest growing economic sectors in the world. Moreover, the growth of tourism in the world has progressed rapidly in the last two decades. In 2014, the tourism sector contributed around US\$ 1.4 trillion in exports or in other words it contributed $5 \%$ of world exports. In addition, this sector also significantly contributes to the growth of the world economy, such as it contributed 9.5\% to Bruto Domestic Product. Besides, this sector is able to create 1 of 11 jobs. Although global crisis has occurred several times, the number of international tourist trips continues to show positive growth, from 25 million people in 1950, then 278 million people in 1980 to 528 million people in 1995 and to 1.1 billion people in 2014 (Ratman, 2016).

Indonesia has indeed abundant natural resource potential, such as the beauty of natural scenery, flora and fauna diversity, ethnic cultural diversity and various historical heritages. These entire things make Indonesia has considerable potential in developing the tourism sector (Fadilah, 2011). Law Number 10 of 2009 stated that tourism development is needed to encourage equal opportunity distribution and benefit as well as able to face the challenges of changes in local, national and global life (Agustini, Siregar, Sipur, \& Almastoni, 2011).

Tourism sector is the only sector which constantly contributes positively to Indonesia's services trade balance (Lumaksono, Priyarso, Kuntjoro, \& Heriawan, 2012). The tourism sector is also the only service sector which is included in ten export commodities with the largest contribution to foreign exchange earnings. Other leading export commodities are oil and natural gas, palm oil, processed rubber, clothing, electrical equipment, textiles, paper and goods from paper, processed food, and chemicals (Kemenparekraf, 2012).

The tourism sector, as well as other economic sectors, has a great opportunity to further develop with the existing liberalization. This happens because of the easier access to intercountry transportation facilities, the people are getting more open to travel abroad, the increase in international trade volume, and the entry and exit of investment from or abroad. Thus, the role of the tourism sector will be increasingly important in globalization era (Lumaksono, Priyarso, Kuntjoro, \& Heriawan, 2012).

Tourism sector within the ASEAN region is included in the twelve priority liberalization sectors for achieving the establishment of ASEAN Economic Community (MEA) 2015.MEA is a form of regional economic integration which primarily aims to increase economic growth of the member countries and strengthen the economic competitiveness of the region facing the competition from other countries. Tourism sector is one of five service sectors included in the priority of liberalization, in which service liberalization means service sectors and sub-sectors are opened by eliminating market access barriers and applying national treatment (Winantyo, et al., 2008).

As a country which has considerable tourism potential, Indonesia, seeing these developments, needs to take an important part to optimize the market share of tourism at the global level. Tourism potentials owned by Indonesia are such as the number of tourism objects which spread throughout all Indonesia's area with very attractive natural conditions to be tourist destinations for natural tourism, marine tourism, agro tourism, cultural tourism, and culinary tourism.

In 2015, Indonesia's national tourism at a macro level shows the development and contribution which continuously increase and get more significant to national GDP of $4.23 \%$ or worthed as much as IDR 461, 36 trillion with an increase in foreign exchange reaching US \$ 11.9 billion and as much as 12.6 million people labor. In addition, there is an increase in the number of 
foreign tourists as many as 10.4 million and domestic tourists are 255, 20 million trips (Ratman, 2016).

At present, Ministry of Tourism sets six main targets of tourism development. First, tourism's contribution to Gross Domestic Product (GDP) increased from 9 percent in 2014 to 15 percent in 2019. Secondly, foreign exchange increased from IDR 140 trillion in 2014 to IDR 280 trillion in 2019. Third, the contribution to employment opportunities increased from 11 million in 2014 to 13 million in 2019. Fourth, tourism competitiveness index increased from rank 70th in 2014 to 30 in 2019. The Fifth, the number of foreign tourist arrivals increased from 9.4 million in 2014 to 20 million in 2019. And the sixth, the number of domestic tourist travel increased from 250 million in 2014 to 275 million in 2019.

In the world market, Indonesia's tourism competitiveness is still relatively low despite the annual increase. According to World Economic Forum (2017), based on The Travel \& Tourism Competitive Index (TTCI) issued since 2007, Indonesia's tourism competitiveness ranked 74th out of 139 countries in 2011. This rank increased from 2009 which was in the 81st and 80th in 2008. In 2015, Indonesia's tourism competitiveness increased to 50th rank from 141 countries and was ranked 42 nd of 136 countries in 2017.

The level of competitiveness of a country's tourism is highly determined by the conditions of regional tourism including the tourism condition in Semarang. Law No. 32 Year 2004 concerning regional autonomy gives broader authority to regional (provincial and regency/municipality) governments to manage their regions has resulted big impact by increasing responsibilities and demands to explore and develop all potential resources owned by the region in order to sustain the development plan in the region, including in tourism sector (Arianti, 2014).

Semarang is an ideal municipality as a gateway to other cities in Central Java. Thus, Semarang is better known as the Municipality of Transit than Municipality of Tourism. In contrast, Semarang has so much uniqueness which can be enjoyed and it has many tourism objects which is worth to visit. The uniqueness of its geological form is rarely found in other cities. In addition, Semarang is as divided into areas with two climates, hot and cool. The hot climate is because the municipality is on the coast of Semarang which is lowland, while the cool climate is due to some of area in Semarang municipality is on the slopes of Mount Ungaran (Culture and Tourism Office of Semarang Municipality, 2012).

Semarang Municipality is a multicultural municipality consisting of various ethnicities. This makes Semarang Municipality has the potential of cultural arts with past cultural arts pillars background which form its current cultural arts, namely Javanese, Chinese, Arabic and Dutch. This, if well developed, can become a tourist attraction which can increase tourist visits both domestic and foreign tourists as well as can make Semarang Municipality as one of national, regional and even international tourist destinations.

Semarang Municipality has many tourism objects which have not been explored for its beauty. In 2017, there were about 41 tourism objects spread throughout Semarang Municipality. Moreover, many tourist attractions and tourist village according to regencies/ municipalities in Central Java can be seen in table 1.

Table 1. The Number of Tourist Attractions and Tourist Village based on Regency / Municipality In Central Java in 2017

\begin{tabular}{lc}
\hline Regency/ Municipality & $\begin{array}{c}\text { Number } \\
\text { of Tourist } \\
\text { Attraction }\end{array}$ \\
\hline Boyolali Regency & 47 \\
Semarang Municipality & 41 \\
Semarang Regency & 41 \\
Kudus Regency & 39 \\
Jepara Regency & 36 \\
Sragen Regency & 35 \\
\hline
\end{tabular}

Source: Youth, Sport and Tourism Service of Central Java

Based on table 1, it can be seen that in 2017 Semarang Municipality has one of the highest tourist attraction and tourist village in Central 
Java, i.e. 41 units followed by Semarang Regency, Kudus, Jepara and Sragen regency.

According to data from Youth, Sport and Tourism Service of Central Java (2017), tourists visiting tourism objects in Semarang Municipality from year to year have increased. In 2017, Semarang municipality has the highest number of visitors compared to other regencies/ municipalities (table 2).

Table 2. The Number of Visitors to Tourist

Attractions and Tourist Village Based on Regency/ Municipality in Central Java in 2017

\begin{tabular}{llll}
\hline Regency/ & \multicolumn{3}{l}{ Number of Visitors } \\
\cline { 2 - 4 } Municipality & $\begin{array}{l}\text { Foreign } \\
\text { Tourists }\end{array}$ & $\begin{array}{l}\text { Domestic } \\
\text { Tourist }\end{array}$ & Number \\
\hline Semarang & 99.282 & 4.198 .584 & 4.297 .866 \\
Municipality & & & \\
Magelang Regency & 315.459 & 3.565 .856 & 3.881 .315 \\
Surakarta & 28.322 & 3.843 .353 & 3.871 .675 \\
Municipality & & & \\
Semarang regency & 9.130 & 2.699 .328 & 2.708 .458 \\
Jepara Regency & 26.127 & 2.132 .073 & 2.158 .200 \\
\hline
\end{tabular}

Source: Youth, Sport and Tourism Service of Central Java

However, regional income originating from the tourism sector of Semarang Municipality is also still inferior when compared to other regions, such as Semarang Regency and Purbalingga Regency. It is such a contrast regarding that Semarang Municipality's tourist visitors are the highest (table 3 ).

Table 3. Regional Income Originating from the Tourism Sector in 2017

\begin{tabular}{ll}
\hline Regency/ Municipality & $\begin{array}{l}\text { Income } \\
(\mathrm{Rp})\end{array}$ \\
\hline Semarang Regency & 49.100 .255 .038 \\
Purbalingga Regency & 33.044 .512 .009 \\
Semarang Municipality & 29.076 .280 .548 \\
Banjarnegara Regency & 17.469 .086 .728 \\
Surakarta Municipality & 16.284 .627 .800 \\
\hline
\end{tabular}

Source: Youth, Sport and Tourism Service of Central Java

Some of tourism problems faced by Semarang municipality are lack of quality tourism, limited tourism infrastructure and limited tourism marketing due to lack of tourism events. This fact indicates that Semarang Municipality tourism industry still lacks of competitiveness.

Competitiveness issue in tourism is quite challenging to study since this strategic issue has not been seriously explored until now. The improvement in tourism competitiveness is seen as a strategic step to enlarge the market share of tourists and optimize the utilization of national tourism potential. Competitiveness highly determines the extent of tourism products ability to penetrate and reach the top position in the increasingly intense global tourist market competition. In addition, every tourist destination is required to be able to show a superior competitive position in order to facilitate more effective promotional and marketing activities in global market. (Damanik, 2013). Competitiveness a very multidimensional concept and there seems to be no generally accepted definition. However, the concept of competitiveness and its implementation in economic development policies have attracted considerable attention by economic experts and policy makers (Saptana, 2010).

Meanwhile, World Economic Forum (WEF) released an indicator of new competitiveness. The concept used is Travel and Tourism Competitive Index (TTCI), i.e. competitiveness index of tourist destination countries which are developed from a number of composite indicators of social, economic, cultural, technological and infrastructure (Damanik, 2013). The indicators arranged are basically almost the same as those used by World Travel and Tourism Council (WTTC), but they are relatively more specific.

There are four main categories of variables considered as capable for promoting tourism competitiveness according to TTCI; they are (WEF, 2017): First, enabling environment, the indicators include: business environment, safety and security, health and hygiene, human resources and labor market and ICT Readiness; second, T \& T Policy and Enabling Conditions, with indicators such as: prioritization of travel and tourism, international openness, price competitiveness, environmental sustainability. 
Third, infrastructure, with some indicators including: air transport infrastructure, ground and port infrastructure and tourist service infrastructure. Fourth, natural and Cultural Resources, including indicators such as: natural resource and business travel

Several studies related to tourism competitiveness have been conducted by such as Trisnawati (2008), Navickas \& Malakauskaite (2009), Barbosa \& Oliveira (2010), Croes (2010), Gupta \& Singh (2015), Alves \& Nogueira (2015), and Panjaitan, Novianti, \& Nugraheni (2016). These studies, moreover, have different indicators of tourism competitiveness. In contrast, the number of research on the competitiveness of regional tourism in Indonesia is still relatively small. These studies include Trisnawati (2008) and Panjaitan et al (2016) which examine the competitiveness of a region's tourism by using competitiveness monitor (CM) indicators.

Triswati's research (2008) analyzes tourism competitiveness by using Competitiveness Monitor (CM) in Yogyakarta and Surakarta. The Panjaitan et al (2016) study analyzed tourism competitiveness using CM in Samosir Regency. Whereas in this study, the authors analyzed tourism competitiveness by using CM for Semarang Municipality, Surakarta Municipality and Magelang Regency. The use of $\mathrm{CM}$ measurements, because $\mathrm{CM}$ is a measure of tourism competitiveness used by the World Travel and Tourism Council (WTTC).

Of those problems, research on competitiveness improvement is very important to provide an overview of the position of tourism competitiveness in Semarang. Competitiveness measurement attracts such significant attention to study since it is a crucial factor for the success of tourism industry. This is important due to by paying attention to the determinants of tourism competitiveness, then the advantages and disadvantages of the area in developing tourism industry as one of the potential GDP (PAD) sources can be assessed. Based on these backgrounds, the objectives of this study are: to analyze the level of tourism industry competitiveness in Semarang Municipality.

\section{RESEARCH METHOD}

The data used in this study are secondary data from Badan Pusat Statistik (BPS) and Culture and Tourism Office of Semarang Municipality. This study uses competitiveness monitor (CM) method as analytical tool. Competitiveness Monitor (CM) is a measuring instrument to determine tourism competitiveness according to World Travel and Tourism Council (WWTC) which consists of 8 indicators, including: Human Tourist Indicator (HTI), Price Competitiveness Indicator (PCI), Infrastructure Development Indicator (IDI), Environment Indicator (EI), Technology Advancement Indicator (TAI), Human Resource Indicator (HRI), Openness Indicator (OI) and Social Development Indicator (SDI) (Trisnawati et al, 2008).

The followings are some Competitiveness Monitor indicators (Trisnawati dkk, 2008): This indicator shows the achievement of regional economic development due to the arrival of tourists in the area. The measurement used is Tourism Participation Index (TPI), i.e. the ratio between the number of tourist activities (coming and going) and the population of the destination area.

TPI $=\frac{\text { The Number of Tourist in Semarang City }}{\text { The number of Population in Semarang City }}$

This indicator shows the price of commodities consumed by tourists during their travel such as costs of accommodation, travel, vehicle rental, and so on. The measurement used to calculate PCI is Purchasing Power Parity (PPP) while the proxy used is the average minimum tariff for hotels which are worldwide hotels, for instances: Novotel and Puri Asri Hotels.

\section{PPP $=$ THe number of foreign tourists $\mathrm{x}$ average of Hotel tariff $x$ average of Hotel stay}

This indicator explains the development of highways, improvement of sanitation facilities and the increase of the population access to clean 
water facilities. In addition, it considers Proxy IDI with per capita income of the population.

This indicator describes the quality of the environment and awareness of the population in maintaining the environment. To calculate the EI, the population density index is used as seen in this following formula:

$$
\mathrm{EI}=\frac{\text { Total Number of Population }}{\text { Total area }}
$$

\section{Technology Advancement Indicator (TAI)}

This indicator shows the development of modern infrastructure and technology which is shown by the widespread use of internet, mobile phone and the export of high-tech products. The measurements used are telephone indexes.

$$
\mathrm{TAI}=\frac{\text { The use of phonelines }}{\text { Total Number of The Population in Semarang City }}
$$

This indicator shows the quality of the regional human resources to provide better services to tourists. In addition, HRI measurement uses pure enrollment rates (PER/APM in Indonesian) at the senior high school level (Panjaitan et al, 2016). Furthermore, PER shows the proportion of students at a certain level who are schooling at the level according to their age group.

This indicator shows the level of the destinations openness to international trade and international tourists. In addition, the measurement uses the ratio of the number of foreign tourists to the total of regional Income (PAD).

$\mathrm{OI}=\frac{\text { The Number of Foreign Tourist }}{\text { Total of Regional Income (PAD) }}$

This indicator describes the comfort and safety of tourists to travel in the destination area. SDI measurement is conducted using human development index

In this study the stages of analysis carried out are:

First, calculating the tourism index from the eight indicators that form the competitiveness index mentioned above with the formula:

$$
\text { Normalization }\left(X_{i}^{c}\right)=\frac{\text { Actual Value }- \text { Minimum Value }}{\text { Maximum Value-Minimum Value }}
$$

Where :

$X_{i}^{c}$ : Normalization coefficient for a location (c) and variable (i)

\section{c : Location}

i : Variable

To determine the tourism competitiveness index, it is necessary to pay attention to the variables that will be calculated one by one according to the indicators of the competitiveness of the potential of the region concerned. Analysis of the calculation of the tourism index is very necessary in analyzing the stature of the potential possessed. With the potential in the area, one of the potentials of the area will be obtained. The aim is to increase the superiority of the destination area with other areas around it.

Second, calculating the composite index of the eight indicators that determine tourism competitiveness.

$$
Y_{k}^{c}=\frac{1}{n} \sum X_{i}^{c}
$$

Where :

$Y_{k}^{c} \quad$ : Composite index $\mathrm{k}(\mathrm{k}=1$ to 8$)$

c : Location

$\mathrm{k} \quad$ : Indicators of competitiveness

$\mathrm{n} \quad$ : Number of variables from $\mathrm{k}$

i : Variable

$\sum X_{i}^{c}$ : Calculation of the sum of each indicator In determining the composite index, it is necessary to note the eight indicators that determine tourism competitiveness because the value of the overall indicators of competitiveness will known. Third, calculating tourism competitiveness index.

$$
Z^{c}=\sum W_{k} Y_{k}^{c}
$$

Where :

$Z^{c} \quad$ : Tourism competitiveness

$Y_{k}^{c}$ : Association weight on each indicator

$\sum W_{k}$ : Calculation of the sum of associations weights for each indicator

The index value "0" shows low competitiveness, while the value "1" shows the ability of high competitiveness / good. 


\section{RESULT AND DISCUSSION}

This study calculates the competitiveness level of Semarang Municipality tourism by using Competitiveness Monitor (CM) based on World Travel and Tourism Council (WTTC). Moreover, there are eight indicators which will be analyzed, including: Human Tourism Indicators (HTI), Price Competitiveness Indicators (PCI), Infrastructure Development Indicators (IDI), Environment Indicators (EI), Technology Advancement Indicators (TAI), Human Resources Indicators (HRI), Openness Indicator (OI) and Social Development Indicator (SDI). As a comparison in this study is the number of tourism in Semarang Municipality with the number of tourism in Magelang Regency and Surakarta Municipality.

Table 4. Quantity of Semarang Municipality Tourism Visit in 2016-2017

\begin{tabular}{lll}
\hline Description & 2016 & 2017 \\
\hline $\begin{array}{l}\text { The length of stay of } \\
\text { foreign tourist }\end{array}$ & $\begin{array}{l}1,97 \\
\text { days }\end{array}$ & $\begin{array}{l}1,97 \\
\text { days }\end{array}$ \\
$\begin{array}{l}\text { The length of stay of } \\
\text { domestic tourist }\end{array}$ & $\begin{array}{l}1,71 \\
\text { days }\end{array}$ & $\begin{array}{l}1,56 \\
\text { days }\end{array}$ \\
\hline
\end{tabular}

Source: Youth, Sport and Tourism Service of Central Java

The condition of tourism in the city of Semarang in the past 7 (seven) years, seen from the number of foreign tourist visits (tourists) and domestic tourists (wisnus) can be seen in table 5 .

Table 5. Number of Visits of Foreign and Domestic Tourist in Semarang Municipality in

\begin{tabular}{llr}
\multicolumn{2}{c}{$2010-2017$} \\
\hline No & Year & $\begin{array}{c}\text { Amount } \\
\text { (Person) }\end{array}$ \\
\hline 1 & 2010 & 1.915 .892 \\
2 & 2011 & 2.100 .926 \\
3 & 2012 & 2.712 .442 \\
4 & 2013 & 3.157 .658 \\
5 & 2014 & 3.750 .351 \\
6 & 2015 & 2.870 .082 \\
7 & 2016 & 3.125 .197 \\
8 & 2017 & 4.297 .866 \\
\hline
\end{tabular}

Source: Youth, Sport and Tourism Service of Central Java
By considering the fact that Magelang Regency and Surakarta Municipality have the highest number of tourists besides Semarang Municipality in 2017. However, the researcher in this study could not calculate TAI indicator due to the limitation in research data. In 2017, based on the Semarang Municipality Government Agency Performance Report, the tourism sector in the municipality of Semarang experienced many developments. This can be seen from several indicators, among others, increasing tourist destination in Semarang Municipality, increasing quantity of tourist visits to the municipality of Semarang, as well as increasing the quality and quantity of tourism infrastructure and supporting facilities (Pemerintah Kota Semarang, 2016).

Table 6. Increasing the Quality and Quantity of Facilities and Infrastucture Semarang Municipality Tourism Object in 2016-2017

\begin{tabular}{lrc}
\hline \multicolumn{1}{c}{ Description } & 2016 & 2017 \\
\hline Hotel occupancy rate & $34,30 \%$ & $33,19 \%$ \\
$\begin{array}{l}\text { Increasing number of } \\
\text { tourist destination }\end{array}$ & 39 & 41 \\
$\begin{array}{l}\text { Type and number of } \\
\text { meals/ restaurants and }\end{array}$ & 403 & 424 \\
$\begin{array}{l}\text { culinary area } \\
\text { Type and number of } \\
\text { tourism business actors }\end{array}$ & 1007 & 1029 \\
\hline
\end{tabular}

Source: Performance Report of Semarang Municipality Government Agencies, 2016

The number of tourist destinations in 2017 was as many as 41 tourism objects, increasing to 39 tourism objects in 2016. Of the 39 objects distinguished by 3 types of tourism namely: 5 natural tourisms, 11 cultural tourisms, 10 artificial tourisms, 12 for the rest tourist attraction and 1 tourist village.

The increase in tourist visits to the municipality of Semarang can be seen from a number of tourist visits. It can be seen in table 4 and table 5 .

The hotel occupancy rate can be seen from two indicators, namely the occupancy rate of the room and the level of usage of the bed. Based on the latest data from the BPS calculation, the 
room occupancy rate in 2017 was $33,19 \%$. The usage rate of beds is $44,95 \%$.

Improving the quality and quantity of tourism facilities and infrastructure as well as supporting facilities can be seen from several indicators including: hotel occupancy rates, number of tourist destinations, number and types of restaurants / restaurants and culinary areas and types and number of tourism business actors (table 7).

Table 7 . Increasing the Quantity of Supporting Facilities for Semarang Municipality Tourism Objects in 2016-2017

Facilities and Infrastructure $2016 \quad 2017$

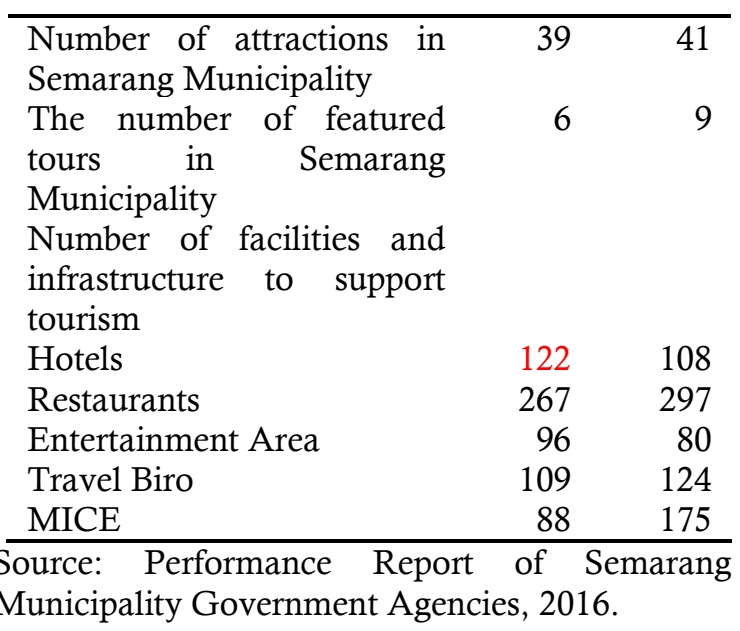

The data of tourism competitiveness index in Semarang Municipality, Magelang Regency and Surakarta Municipality is described in this following table. HTI indicator shows a direct link between tourism and public welfare. Furthermore, the most frequently asked questions are how much the population of a country is involved in tourism activities and how much tourism contributes to the welfare of people in tourist areas. In this study, the calculation of HTI is conducted using the ratio of tourists and population. In other words, this index intends to show whether tourism significantly contributes to the improvement of public welfare in general. The results show that Semarang Municipality HTI (2.57) is lower than that of Surakarta Municipality (3.21) and Magelang Regency (8.08). moreover, the contribution of tourism sector in Semarang Municipality to the welfare of the population/people of Semarang municipality is still less than that of in Magelang Regency and Surakarta Municipality.

Table 7. Tourism Competitiveness Index

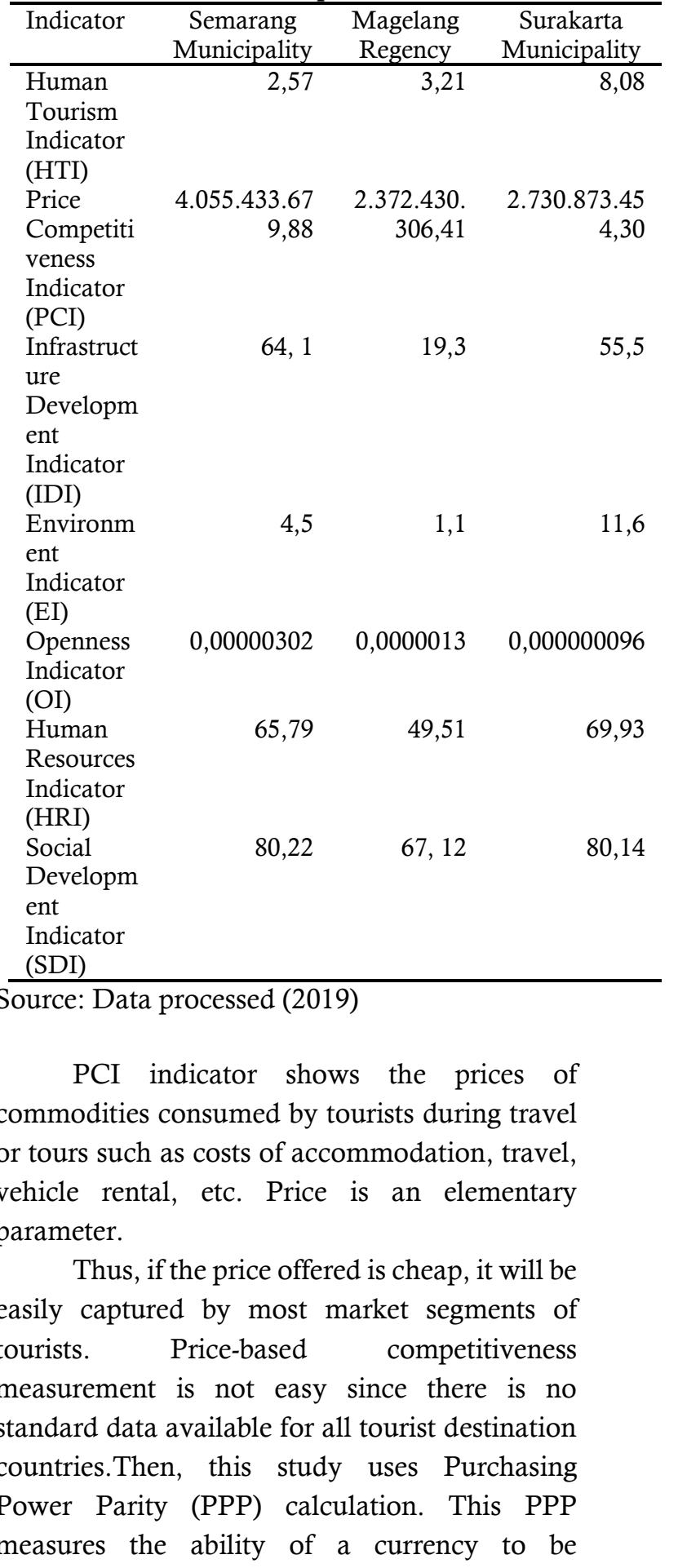


exchanged in international markets. The result shows that PPP index in Semarang Municipality is higher when it is compared to that of Magelang Regency and Surakarta Municipality.

IDI indicator explains the availability of qualified infrastructure which more clearly describes the physical progress of a destination that can answer to what extent the mobility and flow of goods and services are with a level of comfort that can take place in a tourist destination. Infrastructure component consists of easy access to public and tourism facilities, transportation networks, sanitation and drinking water facilities. The calculation of IDI indicator uses income proxy per capita. Moreover, the results of the calculation show that IDI indicator in Semarang municipality $(64,1)$ is higher than in Magelang Regency $(19,3)$ and Surakarta Municipality $(55$,$) . This means the comparison$ between GDP of Semarang Municipality and the population is quite high. Accordingly, the local governments have a very important role in increasing its regional GRDP.

EI indicator tells the originality and uniqueness of the tourist area in a region characterized by low levels of pollution and original/natural environmental condition. The originality of environmental conditions is the most hunted thing by tourists. The guarantee that the environment is free from pollution is a new strength of tourism destinations in attracting visitors/tourists. The wealth of natural resources in developing countries is a great opportunity to make tourism as a motor of development. Environmental guarantees which are free from pollution are a new force for tourist destinations in attracting visitors/tourists. This environmental element includes regulations which are environmentally oriented in a tourist destination country, level of attention and progress made in natural conservation, $\mathrm{CO} 2$ emissions and the number of ratified international agreements. This study uses population density index, i.e the ratio between population and area. The implication is that if an area has a high population density index, then the environmental quality of the area is low. The calculation results show that Semarang municipality's EI indicator (4.5) is still low when compared to Surakarta Municipality (11.6). Nevertheless, it is higher compared to Magelang Regency (1.1). Semarang people are expected to be able to protect the environment, for example by not throwing the garbage not in the right place. This index implies that if a destination area has a very high population density, it is assumed that the environmental quality of the destination will be low. Environmental quality will affect the comfort of tourists who come to these destinations. In general they want a clean, comfortable and safe destination and a refreshing natural atmosphere. The level of population density in both destinations is not significantly different. So the thing that needs to be done is awareness of the population to protect their environment so that the environment becomes clean and beautiful will make tourists feel at home in the destination area.

OI indicator shows that an area has a network and the ease of interacting with the outside world. A country can be classified as having strong potential competitiveness if it has a network and the ease to interact with the wide open world In a special sense, openness refers to the willingness to accept and conduct international trade transactions. In tourism competitiveness context, regional (regency/Municipality/Province) tourism will be able to compete if the ease of obtaining a visa for a short visit is available. This indicator calculation uses the ratio between the number of foreign tourists and the total Regional Income/Revenue (PAD). The calculation results show that OI indicator of Semarang Municipality (0.00000302) is higher than that of Surakarta Municipality (0.000000096) and Magelang Regency (0.0000013). This indicator implies that with the arrival of foreign or international tourists causing trade between the two countries namely the country of origin of tourists and the country of tourist destination. It should be realized that the purpose of tourist arrivals to a destination area is on vacation, doing trade and other purposes such as seminars, education and health. With the diversity of tourists from various 
countries who come to the destination area causing trade.

HRI indicator provides the information on the quality of a tourism service produced and conducted by tourism actors in tourist destinations. Measuring human resources quality can be conducted by using indicators of life expectancy, illiteracy, education, unemployment, training, skills, and gender This study uses pure enrollment rates for high school to measure it. Pure Participation Rate of Semarang Municipality is 65.79. This means that the proportion of students (school children) at senior high school level who attends the education levels according to their age group is 65,79 . In conclusion, Pure Participation Rate of Semarang Municipality is lower than that of Surakarta Municipality, but is still higher compared to Magelang Regency. This indicator shows the quality of human resources in the area so that it can provide better services to tourists. This index implies that the higher the education level of the population in the destination area is assumed to be to provide better services to tourists in the destination area. They understand that the more tourists who come and the longer tourists stay in the destination area, it will provide many benefits to the destination area. One of the benefits obtained is regional income from the tourism sector. The high regional income is assumed to increase the welfare of the population in the detention area and the rate of economic development in the destination area is also increasing.

SDI indicator is different from human tourism (HRI) index. In addition, this indicator refers to human development index. A tourist destination will have high competitiveness if at least in the country as a whole there is a low level of crime and poverty. Since this will affect the comfort in traveling as well as forming a positive image of a tourist destination. This study uses human development index (HDI) indicator. Furthermore, HDI in Semarang is quite high, at 80,22 compared to that of Magelang Regency $(67,12)$ and Surakarta Municipality $(80,14)$. This HDI data is also parallel with the average length of stay. The average length of stay of tourists in
Semarang Municipality is 1,58 days longer than in Magelang Regency t (1,32 days) and Surakarta Municipality (1,37 days). To increase HDI of Semarang Municipality, it is certainly the duty of Semarang municipality government, such as by increasing life expectancy, literacy rates and GRDP of Semarang Municipality. This index implies that the longer tourists stay in the destination area, the more shopping or consumption will be spent in the area. In terms of macroeconomics, the more consumption or expenditure made by tourists in the destination area will increase income in the destination area.

\section{CONCLUSION}

Semarang Municipality has several lower indicators of competitiveness calculation compared to those of Surakarta Municipality and Magelang Regency, including Human Tourism Indicator (HTI), Environment Indicator (EI), and Human Resources Indicator (HRI). However, Semarang Municipality has several higher indicators of competitiveness calculation than those of Surakarta Municipality and Magelang Regency, i.e. Price Competitiveness Indicator (PCI), Infrastructure Development Indicator (IDI), Openness Indicator (OI) and Social Development Indicator (SDI).

The improvement of tourism competitiveness in Semarang Municipality requires synergy from many parties, including the government of Semarang municipality as policy makers, business actors in tourism sector (hotel owners, travel bureaus), private sector and academics. Based on the results of the study, it is seen that Semarang Municipality has a low indicator than other regions.

Improving Human Tourism Indicator (HTI) can be done by inviting the active role of the community (people/population) in tourism activities, for example creating Semarang souvenirs and typical Semarang food. Besides, the Government can hold national and international scale activities as forum business activities, sports, cultural arts, etc. consequently, it can invite more domestic and foreign tourists to come. To increase the number of foreign tourists visiting Semarang can be done in various 
ways, such as promotion of tourism in Semarang municipality through internet/web and making various kinds of international events which highlight local wisdom of Semarang. Moreover, improving the quality of the entrance to Semarang for tourists, i.e. by improving the quality of airports and also sea port is also can be conducted. Environment indicator (EI) can be improved by inviting Semarang population to protect the environment, for example by not throwing garbage carelessly. Semarang Municipality Government may also take part in protecting the environment by planting trees, flowers, building municipality parks, providing several trash bins along the road, and rebuilding rivers in Semarang municipality to be clean. In addition, improving Human Resources Indicators can be carried out by conducting education related to tourism to the managers of tourism objects and to the surrounding people.

The limitation of this study is because it only compares the municipality of Semarang with two other regions in Central Java, namely Surakarta and Magelang. The next research can be done by comparing all regions in Central Java.

\section{REFERENCES}

Agustini, F., Siregar, H., Sipur, \& Almastoni, 2011. Overview of Local Government Policy Related to the Development of Tourism in North Sumatra (Medan Special Case Study). Medan: North Sumatra Government Research and Development

Agency.Alves, S., \& Nogueira, A. R, 2015. Towards a Sustainable Tourism Competitiveness Measurement Model For Municipalities: Brazilian Empirical Evidence. Revista de Turismo y Patrimonio Cultural, 13( 6), 13371353.

Barbosa, L. G., \& Oliveira, C. T, 2010. Competitiveness Of Tourist Destinations : The Study Of 65 Key Destinations For The Development Of Regional Tourism. Revista De Administracao Publica , 1067-1095.

Croes, R, 2010. Small Island Tourism Competitiveness: Expanding Your Destinations's Slice Of Paradise. Florida: Rosen College Of Hospitality Management .

Damanik, J, 2013. Indonesian Tourism: Between Opportunities and Challenges. Yogyakarta: Student Library.
Gupta, S., \& Singh, A, 2011. Determinatns of Tourism Destinations Competitiveness: A Case Of Bundelkhand India. International Journal of Management Research , .6 (2) , 47-62.

Kemenparekraf, 2012. Performance Statistics of the Ministry of Tourism and Creative Economy. Jakarta: Ministry of Tourism and Creative Economy.

Komsic, J., \& Dorcic, J, 2016. Tourism Destination Competitiveness and Online Reputation: Conceptualization and Literature Framework Analysis. Tourism \& Hospitality Industry Conference, 144-157).

Lumaksono, A., Priyarso, D., Kuntjoro, \& Heriawan, $\mathrm{R}, 2012$. The Impact of International Tourism Economics on the Indonesian Economy. Postgraduate Forum, 35 (1), 53-68.Navickas, V., \& Malakauskaite, A, 2009. The Possibilities For The Identification And Evaluation Of Tourism Sector Competitiveness Factors. Engineering Economics No.1 (61) , 37-44.

Panjaitan, D. V., Novianti, T., \& Nugraheni, S. R, 2016. The Tourism Competitiveness Index Of Indonesia In The Effort To Improve The Workforce Absorption In Tourism Sector. Economics and Finance Review Vol. 4 (08) , 0107.

Semarang City Government, 2016. Performance Reports of Semarang City Government Agencies 2015. Semarang: Semarang City Government.

Ratman, D. R, 2016. Priority Tourism Destination Development 2016-2019. Jakarta: Ministry of Tourism

Saptana, 2010. Conceptual Review of Micro-Macro Competitiveness and Agricultural Development Strategy. Agro Economic Research Forum Vol. 28 No.1, 1-18.

Saputra, R., \& Winantyo, R, 2008. ASEAN Economic Community (AEC) 2015: strengthening ASEAN Synergy in the Middle of Global Competition. Jakarta: PT Elex Media Komputindo.

Trisnawati, R., Wiyadi, \& Priyono, E, 2008. Analysis of The Competitiveness Tourism Industries Increasing The Local Economy (The Comparative Study Analysis Of The Competitiveness Tourism Between Surakarta and Yogyakarta). Economic Journal of Emerging Market Vol. 3 No. 2 .

WEF, 2017. The Trael and Tourism Competitiveness Report. Geneve: World Economic Forum.

Winantyo, R., Saputra, R., Fitriani, S., Morena, S., Kosotali, A., G, S., et al, 2008. The ASEAN Economic Community (AEC) 2015: Strengthening ASEAN Synergy Amid Global Competition. Jakarta: PT. Elex Media Komputindo. 